\title{
Developing a 3-D model for the Skaergaard intrusion in East Greenland: constraints on structure, mineralisation and petrogenetic models
}

\author{
Troels F.D. Nielsen, Símun D. Olsen and Bo M. Stensgaard
}

The Skaergaard intrusion (Fig. 1) is probably the most studied layered gabbro intrusion in the world (Wager \& Deer 1939; Wager \& Brown 1968; McBirney 1996; Nielsen 2004). The intrusion is $c .54 .5 \mathrm{Ma}$ old and was formed during the Palaeogene opening of the North Atlantic Ocean, intruding into the base of the East Greenland flood basalts. The intrusion is relatively small with a volume of $c .300 \mathrm{~km}^{3}$ (Nielsen 2004). Spectacular magmatic layering and systematic evolution in the compositions of liquidus phases and estimated melt compositions (e.g. Wager \& Brown 1968) have made the intrusion the most studied example of the development of the 'Fenner trend' of iron enrichment in basaltic liquids (e.g. Thy et al. in press; Veksler in press).

The identification in the late 1980s of significant platinum-group elements (PGE) and gold ( $\mathrm{Au}$ ) occurrences in the intrusion (e.g. Bird et al. 1991; Nielsen et al. 2005) has led to continued investigation and exploration drilling. The Skaergaard intrusion is suggested to hold $c .33$ million ounces (1000 tonnes) of PGE and c. 13 million ounces (400 tonnes) of $\mathrm{Au}$ (Nielsen et al. 2005). The mineralised zone is located in a c. $100 \mathrm{~m}$ thick zone of anomalous PGE and Au enrichment in the upper part of the Middle zone (Bird et al. 1991; Nielsen et al. 2005) of the Layered series. The mineralised zone consists of a succession of bowl-shaped, stratiform and very tightly controlled levels of palladium $(\mathrm{Pd})$ enrichment

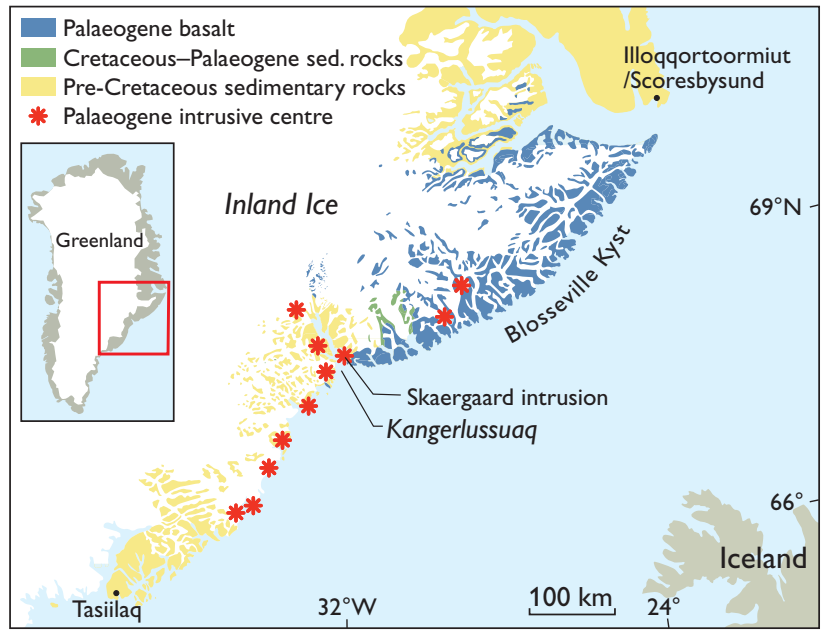

Fig. 1. The Skaergaard intrusion is located in the Kangerlussuaq region in the Palaeogene magmatic province in East Greenland. referred to as Pd1 to Pd5 (Fig. 2; Nielsen et al. 2005). The bottom level, Pd5, is developed from margin to margin of the intrusion, whereas the overlying levels $\mathrm{Pd} 4$ to $\mathrm{Pd} 1$ are increasingly restricted in width, and the entire succession of Pd levels is only developed in the central part of the intrusion. The structure of the mineralised zone can be compared to a set of bowls with upward-decreasing diameters. Gold is always concentrated in the uppermost palladium levels or in a level above the top palladium level, irrespective of the number of developed Pd levels. More detailed descriptions are provided by Nielsen et al. (2005).

The exploration drill cores provide material and structural information from previously inaccessible parts of the intrusion (Nielsen et al. 2005). The 3-D image presented in Fig. 4 is based on drill-core information (petrographical, petrophysical, geochemical etc.) and surface information. It allows an unprecedented insight into the internal structure of the upper part of the intrusion and offers a possibility of refinement of volume estimates and quantitative modelling of the

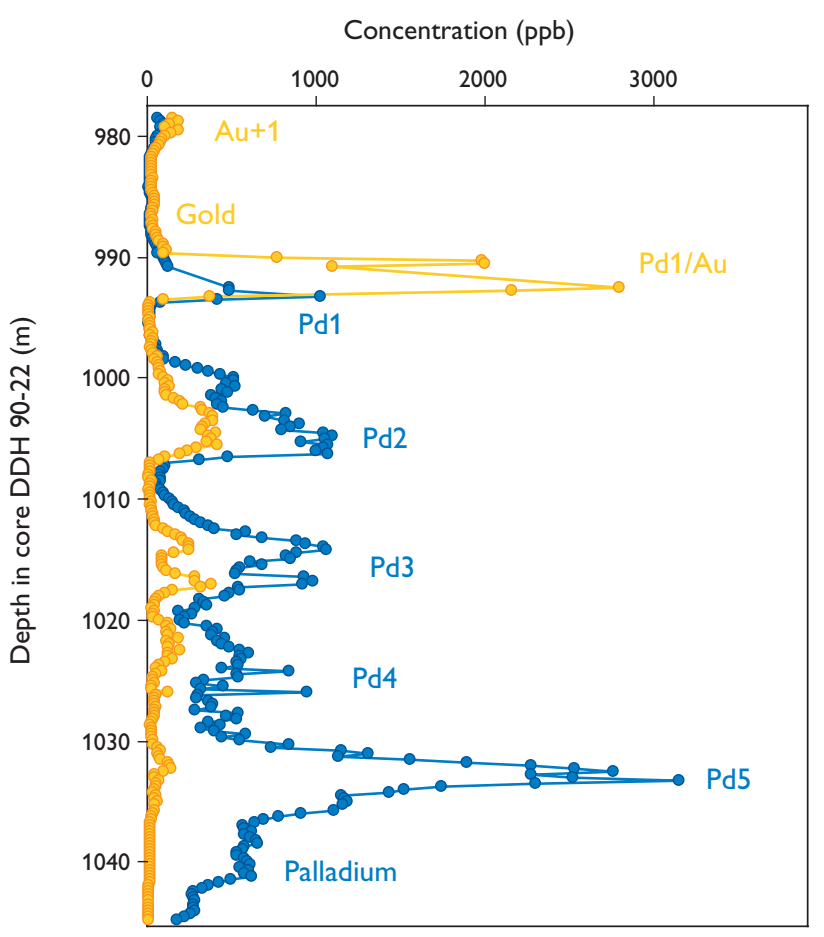

Fig. 2. Characteristic variation in whole-rock Pd concentration in the central parts of the Skaergaard mineralised zone (core DDH 90-22, from Bernstein \& Nielsen 2004). 


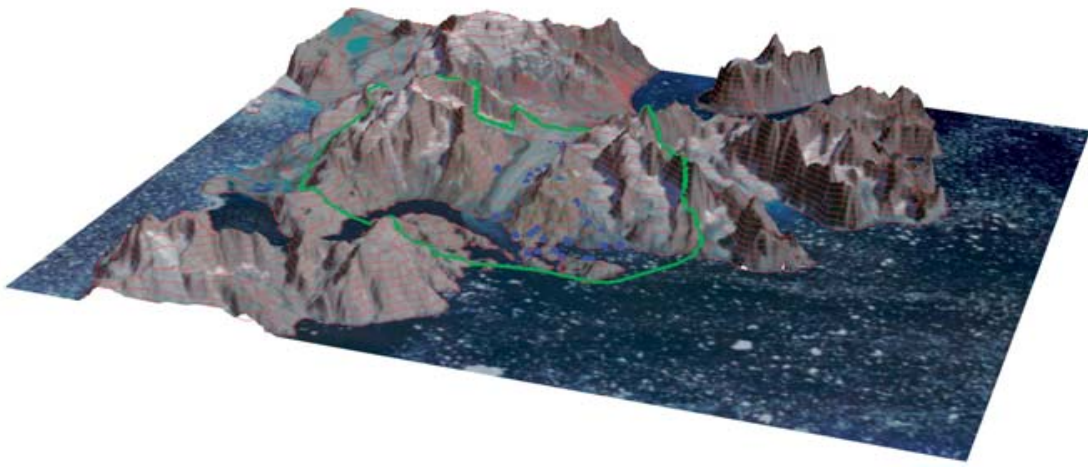

zones and subzones of the intrusion. A constrained structural model will in turn allow evaluation and revision of crystallisation models for the basaltic liquid in the magma chamber.

\section{3-D modelling of the intrusion and the mineralised zone}

The initial aim of the 3-D modelling was a visualisation of the intrusion and the associated PGE and Au mineral occur-

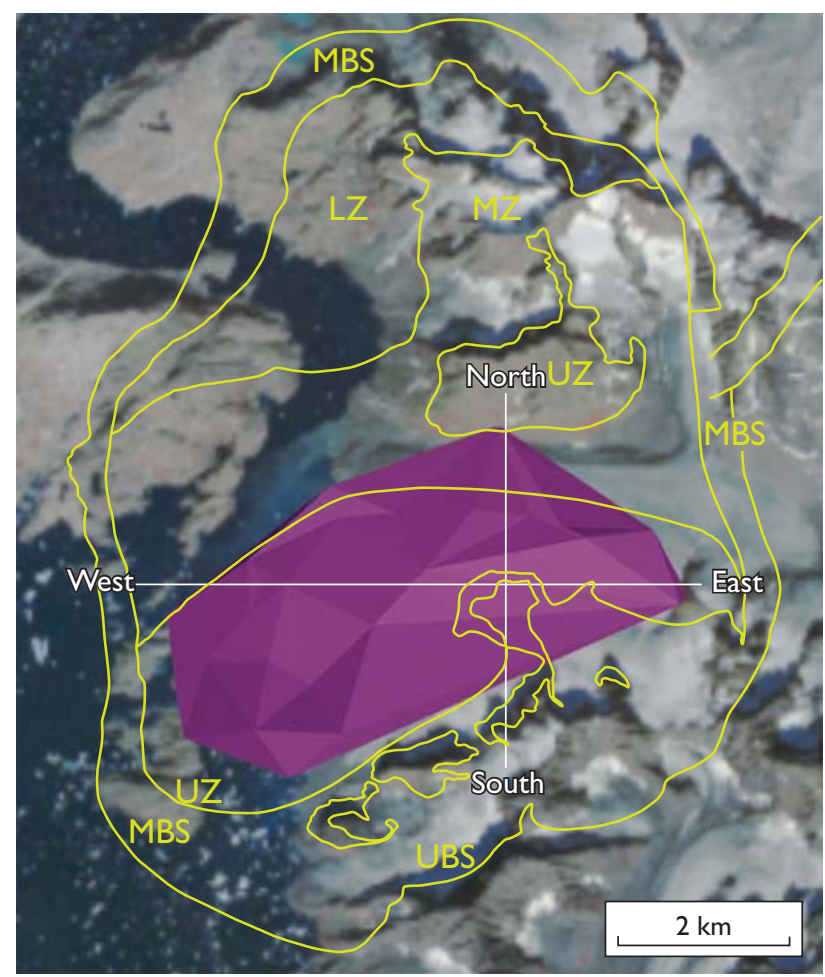

Fig. 4. Satellite image showing the area of the mineralised zone so far covered by the 3-D model (purple area) with the geological boundaries transferred from the geological map of the Skaergaard intrusion (McBirney 1989). MBS, Marginal Border Series (wall rocks); UBS, Upper Border Series (roof rocks); Layered series (LS; floor rocks) consisting of $\mathbf{L Z}$, Lower Zone; $\mathbf{M Z}$, Middle Zone; UZ, Upper Zone. Islands in UBS: the younger Basistoppen Sill The two white lines show the location of the 2-D cross-sections (Fig. 5). Abbreviations also apply to Table 1 and Fig. 6.
Fig. 3. ASTER satellite image with topography $(1.5 \times$ vertical exaggeration; see text for explanation). The green line shows the outer boundary of the Skaergaard intrusion, and the blue dots show the locations of the collars of drill holes.

rences. Geographical information system software was used for the compilation of the surface data used for the model. These data, together with subsurface data, were subsequently imported into modern 3-D mining and resource software (Gemcom GEMS $^{\circledR}$ ), which was used for the construction of the 3-D model of the intrusion and its mineralised zone.

The detailed topographical model needed for the modelling (Fig. 3) was constructed from satellite Aster data (resolution $30 \times 30 \mathrm{~m}$ ). Aster scenes and the 1:20 000 scale geological map of the intrusion and adjacent area were draped on the terrain model.

Forty-one cores with a total length of $23425 \mathrm{~m}$ have been drilled since 1989. The deepest holes reached levels of $c .1200 \mathrm{~m}$ below the collars of the drill holes. The petrographic variation in all these cores is described in drill-hole logs in company reports in the archives of the Geological Survey of Denmark and Greenland. These logs were digitalised and compiled. The courses of the drill holes (taking azimuth and dip into account) were visualised in 3-D, and assays for PGE and Au displayed together with the petrographic information. All the information was subsequently assessed for each drill hole, and the delineation of specific lithologies and mineralised sections was interpolated manually by the geologist software operator from one drill hole to another and from drill holes to surface exposures of the mineralised zone. Triangulation surfaces were constructed mathematically by the GEMS software from the delineations and united into wire-frames that represent 3-D solids (geological bodies). The delineation and resulting solids were validated by the software. Dykes in the intrusion were also modelled as solids. Mapped-out fault planes were visualised as 3-D surfaces.

In intrusion-wide images the mineralised zone is a very narrow structure. The 3-D model is best seen 'live', and we have chosen, as examples, to show the initial results of the imaging of the mineralised zone in two vertical 2-D panels through the intrusion (Figs 4, 5). In Fig. 5 the mineralised zone is shown as the zone between the lower boundary of the lowermost Pd-levels (Pd5, cut-off at $c .1$ gram per tonne Pd) and the top of the Au-rich part of the mineralised zone $(\mathrm{Pd} 1 / \mathrm{Au}$ or $\mathrm{Au}+1$ levels, cut-off at $c .0 .8$ gram per tonne $\mathrm{Au})$. 


\section{Results}

The west-east section of Fig. 5A shows the mineralised zone to be bowl-shaped with a central depression of $c .400 \mathrm{~m}$. The magnitude of the depression is in broad agreement with the margin-to-margin depression of $c .700 \mathrm{~m}$ modelled by Nielsen (2004) and Nielsen et al. (2005). The difference in the magnitude of the depression reflects that the 3-D model does not reach all the way to the margins of the intrusion. As expected, the imaging also shows that the vertical distance between the lower and upper boundaries of the mineralised zone increases towards the centre of the intrusion, in agreement with the structure of the mineralised zone proposed by Nielsen et al. (2005). The demonstrated bowl-shape of the mineralised zone, and thus the layered gabbros, corroborates the model suggesting concentric crystallisation of the gabbro on the floor, walls and below the roof of the intrusion (Nielsen 2004). The north-south section (Fig. 5B) shows the general $20^{\circ}$ dip of the layered gabbros and the mineralised zone.

\section{Application of 3-D modelling to the evolution of the Skaergaard intrusion}

Nielsen (2004) developed a structural model for the intrusion solely on the basis of field observations and analogies. Compared to the classic and traditional accumulation models, the apparent concentric crystallisation in the $300 \mathrm{~km}^{3}$ magma chamber reduces the volumes of the most evolved zones and subzones in the intrusion and thus the proportions of the products of the crystallisation process.
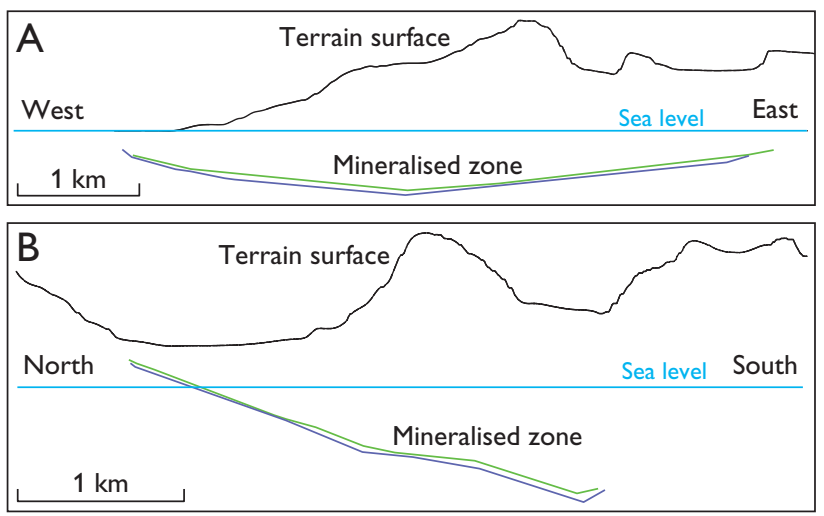

Fig. 5. West-east (A) and north-south (B) cross-sections through the Skaergaard intrusion. The blue and green lines show the lower and upper boundaries of the Skaergaard mineralised zone (see text for definition). The bowl-shape and the increasing stratigraphic width of the mineralised zone towards the centre of the intrusion are seen (see also Nielsen et al. 2005).

The model was used for a mass balance-based estimate of the bulk composition of the intrusion, which turned out to be a composition very similar to that of the contemporaneous flood basalts. The data in Nielsen (2004) can also be used for the calculation of the line of liquid descent (LLD) of the bulk liquid (Fig. 6; Table 1). Toplis \& Carroll (1995) modelled the LLD for the Skaergaard intrusion on the basis of experimental investigations. As shown in Fig. 6 the trend of the supposed Skaergaard liquid of Toplis \& Carroll (1995) has the same shape as the one calculated using mass balance (Table 1). The data in Fig. 6 are projected from the $\mathrm{SiO}_{2}$ corner above the plane in the figure, and the difference between the Toplis \& Carroll (1995) and the LLD suggested here is a reflection of differences in the starting compositions.

Table 1. Compositions of liquids during the fractionation of the Skaergaard magma

\begin{tabular}{|c|c|c|c|c|c|c|c|c|}
\hline & $\begin{array}{c}\text { Bulk } \\
\text { SK-TFDN }\end{array}$ & $\begin{array}{l}\mathrm{L} 1 \\
\mathrm{LZb}\end{array}$ & $\begin{array}{l}\mathrm{L} 2 \\
\mathrm{LZc}\end{array}$ & $\begin{array}{l}\text { L3 } \\
M Z\end{array}$ & $\begin{array}{c}\mathrm{L} 4 \\
\mathrm{UZa}\end{array}$ & $\begin{array}{c}\text { L5 } \\
\text { UZb }\end{array}$ & $\begin{array}{l}\mathrm{L} 6 \\
\mathrm{UZc}\end{array}$ & $\begin{array}{l}\text { L7 } \\
\text { MG }\end{array}$ \\
\hline$\%$ solidified & 0.00 & 32.74 & 55.26 & 62.56 & 75.81 & 85.57 & 93.43 & 95.00 \\
\hline $\mathrm{SiO}_{2}$ & 47.88 & 47.03 & 45.92 & 46.52 & 48.19 & 50.73 & 58.45 & 62.08 \\
\hline $\mathrm{TiO}_{2}$ & 3.03 & 3.74 & 4.86 & 4.63 & 3.74 & 2.65 & 1.40 & 1.07 \\
\hline $\mathrm{Al}_{2} \mathrm{O}_{3}$ & 13.87 & 11.93 & 11.24 & 11.15 & 10.75 & 10.42 & 11.35 & 12.39 \\
\hline $\mathrm{Fe}_{2} \mathrm{O}_{3}$ & 2.00 & 2.34 & 2.70 & 2.72 & 2.80 & 2.78 & 2.12 & 1.63 \\
\hline $\mathrm{FeO}^{2}$ & 13.32 & 15.63 & 17.97 & 18.12 & 18.64 & 18.53 & 14.13 & 10.88 \\
\hline $\mathrm{MnO}$ & 0.22 & 0.26 & 0.29 & 0.30 & 0.32 & 0.34 & 0.29 & 0.20 \\
\hline $\mathrm{MgO}$ & 6.29 & 6.18 & 4.62 & 4.15 & 3.16 & 1.83 & 0.56 & 0.63 \\
\hline $\mathrm{CaO}$ & 10.16 & 9.62 & 8.78 & 8.55 & 7.89 & 7.37 & 5.89 & 4.64 \\
\hline $\mathrm{Na}_{2} \mathrm{O}$ & 2.56 & 2.48 & 2.61 & 2.71 & 2.94 & 3.18 & 3.78 & 4.18 \\
\hline $\mathrm{K}_{2} \mathrm{O}$ & 0.40 & 0.44 & 0.55 & 0.61 & 0.79 & 1.07 & 1.63 & 1.99 \\
\hline $\mathrm{P}_{2} \mathrm{O}_{5}$ & 0.27 & 0.35 & 0.47 & 0.54 & 0.78 & 1.10 & 0.42 & 0.31 \\
\hline Sum & 100.00 & 100.00 & 100.01 & 100.00 & 100.00 & 100.00 & 100.02 & 100.00 \\
\hline $\mathrm{Mg}$ No. & 0.457 & 0.413 & 0.314 & 0.290 & 0.232 & 0.150 & 0.066 & 0.094 \\
\hline
\end{tabular}

Based on bulk liquid SK-TFDN in Nielsen (2004). The composition of the liquid as it evolves is calculated by subtraction of average compositions of correlated LS, MBS and UBS subzones (McBirney 1989) in the mass proportions in Nielsen (2004). The spread sheet with the calculation is available on request. The composition of the liquid of a specific zone refers to the composition of the liquid at the base of the indicated zone. Bulk composition is corrected so that the end-result matches the composition of average melanogranophyre $(\mathrm{MG})$. $\mathrm{Fe}_{2} \mathrm{O}_{3} / \mathrm{FeO}$ has been set at 0.15 . The abbreviations are explained in Fig. 4 . 
The LLD of the Skaergaard intrusion is of utmost scientific interest. Well-constrained deviations from the expected can be reflections of processes that have not been taken into account in the modelling of the fractionation process. The lack of balance in the $\mathrm{SiO}_{2}$ distribution, as reflected in the common quartz-normative compositions of the Upper Border Series of the intrusion (Naslund 1984), was suggested to reflect chemical stratification of the cooling magma (Hoover 1989). But what process would have been responsible for the chemical stratification? $\mathrm{SiO}_{2}$-enrichment in the upper part of the magma chamber could be due to liquid immiscibility (e.g. Jakobsen et al. 2005) or dynamic conditions. Only with well-constrained mass balances and geophysical models for the shape of the magma chamber can numeric models for the evolution of the Skaergaard intrusions be developed and the relative importance of all the suggested processes in the evolution of the melt evaluated.

All well-constrained internal boundaries and the details of the mineralised zone (bulk chemistry, lithologies and mineralogy) in the Skaergaard intrusion will be included in the 3 -D model in the coming years. This will allow refinement of the 3-D distributions and volumes of different lithologies,

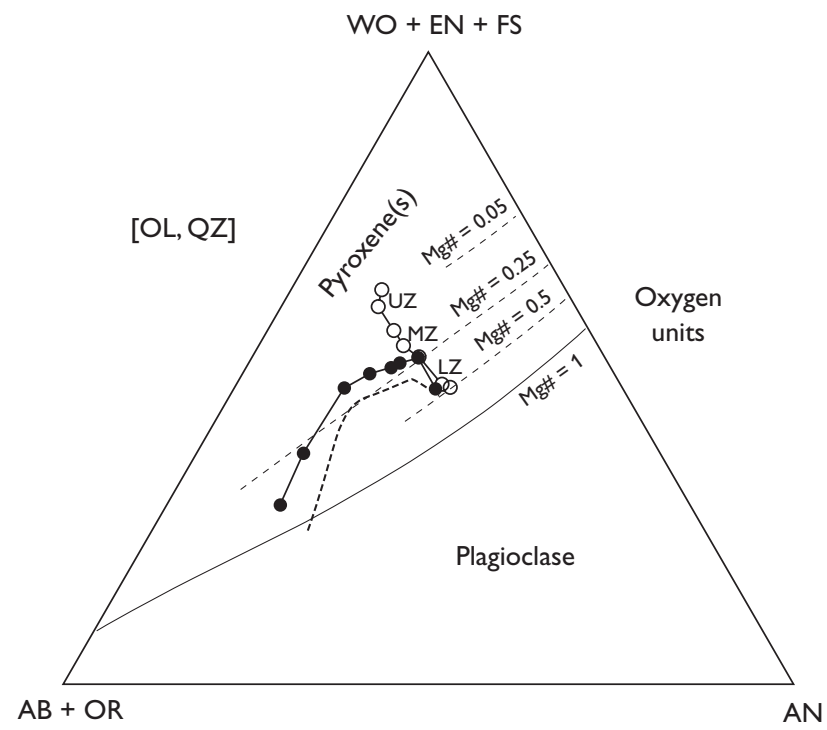

Fig. 6. Skaergaard liquid lines of descent and immiscible liquids in the (Ab + Or)-An-(Wo + En + Fs) projection from Veksler (in press), who used the LLD compositions shown in Table 1 . Black dots: model liquids in the same sub-zones of the layered series calculated by mass balance (Table 1). Circles: trapped Skaergaard liquids (McBirney \& Naslund 1990). Thick dashed curve: experimental line of liquid descent (Toplis \& Caroll 1995). The dashed lines show the boundary between plagioclase and pyroxene crystallisation fields at different $\mathrm{Mg}$ numbers $(\mathrm{Mg} / \mathrm{Mg}+\mathrm{Fe}$; see Veksler in press for details). including the mineralised zone, lead to more advanced massbalance models for the Skaergaard intrusion, and provide more general constraints for modelling of the crystallisation and fractionation processes in basaltic magma chambers.

\section{References}

Bernstein, S. \& Nielsen, T.F.D. 2004: Chemical stratigraphy in the Skaergaard intrusion. Danmarks og Grønlands Geologiske Undersøgelse Rapport 2004/123, 31 pp. + 1 CD.

Bird, D.K., Brooks, C.K., Gannicott, R.A. \& Turner, P.A. 1991: A goldbearing horizon in the Skaergaard Intrusion, East Greenland. Economic Geology 86, 1083-1092.

Hoover, J.D. 1989: Petrology of the Marginal Border Series of the Skaergaard Intrusion. Journal of Petrology 30, 399-439.

Jakobsen, J.K., Veksler, I.V., Tegner, C. \& Brooks, C.K. 2005: Immiscible iron- and silica-rich melts in basalt petrogenesis documented in the Skaergaard intrusion. Geology 33, 885-888.

McBirney, A.R. 1989: Geological map of the Skaergaard intrusion, East Greenland. Eugene, USA: University of Oregon.

McBirney, A.R. 1996: The Skaergaard Intrusion. In: Cawthorn, R.G. (ed.): Layered intrusions, 147-180. Amsterdam: Elsevier.

McBirney, A.R. \& Naslund, H.R. 1990: The differentiation of the Skaergaard intrusion. A discussion of Hunter and Sparks (Contributions to Mineralogy and Petrology 95, 451-461). Contributions to Mineralogy and Petrology 104, 235-240.

Naslund, H.R. 1984: Petrology of the Upper Border Series of the Skaergaard Intrusion, East Greenland. Journal of Petrology 25, 185-212

Nielsen, T.F.D. 2004: The shape and volume of the Skaergaard intrusion, Greenland: implications for mass balance and bulk composition. Journal of Petrology 45, 507-530.

Nielsen, T.F.D., Andersen, J.C. $\varnothing$ \& Brooks, C.K. 2005: The Platinova Reef of the Skaergaard intrusion. In: Mungal, J.E. (ed.): Exploration for platinum group element deposits. Mineralogical Association of Canada Short Course Series 35, 431-455.

Thy, P., Lesher, C.E. \& Tegner, C. in press: The Skaergaard liquid line of descent revisited. Contributions to Mineralogy and Petrology.

Toplis, M.J. \& Carroll, M.R. 1995: An experimental study of the influence of oxygen fugacity on Fe-Ti oxide stability, phase relations, and mineral-melt equilibria in ferro-basaltic systems. Journal of Petrology 36, 1137-1170.

Veksler, I.V. in press: Extreme iron enrichment and liquid immiscibility in mafic intrusions: experimental evidence revisited. Lithos.

Wager, L.R. \& Brown, G.M. 1968: Layered igneous rocks, 588 pp. Edinburgh: Oliver \& Boyd.

Wager, L.R. \& Deer, W.A. 1939: Geological investigations in East Greenland, part III. The petrology of the Skaergaard Intrusion, Kangerdlugssuaq, East Greenland. Meddelelser om Grønland 105(4), 352 pp. 